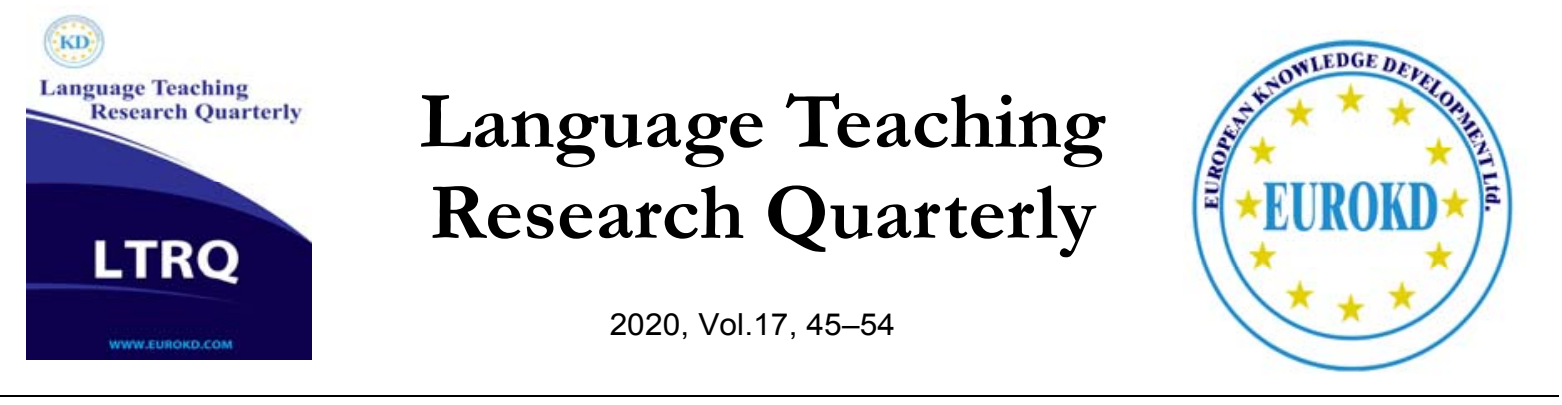

\title{
Interculturalism in Content and Language Integrated Learning Classes: Research Perspectives from European Policy to Greek Reality
}

\author{
Georgios Sakellariou ${ }^{1 *}$, Isaak Papadopoulos² \\ ${ }^{1} \mathrm{MA}$ in English Language \& Literature, European University Cyprus, Cyprus \\ ${ }^{2}$ Teaching Staff -Linguistics, European University Cyprus , Cyprus
}

Special Issue: Interculturalism in Second Language Teaching

Received 28 December 2019 Accepted 16 March 2020

\begin{abstract}
The CLIL (Content and Language Integrated Learning) approach has been proposed as an effective approach for students' education in the 21 st century. Although it was initially proposed for students of higher education, CLIL has become especially attractive for students even in pre-school education. This paper focuses on the importance of CLIL implementation in fostering intercultural competencies among students who are engaged in CLIL programs. More specifically, this paper covers a theoretical review on CLIL and its development, while special emphasis is placed on the position of CLIL in the priorities of the European Council within the context of promoting multilingualism in Europe. CLIL aligns itself with the European Language Policy of improving language learning in its member states and with the EU Commission's objective of EU citizens' competence in European languages other than learners' mother tongue. The paper ends with references to organizations that promote the implementation of CLIL across Europe, while special emphasis is placed upon CLIL in Greek education.
\end{abstract}

Keywords: CLIL, Interculturalism, European Policy, Greek Education, Multilingualism 


\section{Theoretical Review and Backdrop}

Content and Language Integrated Learning (CLIL) can be defined as "a dual-focused educational approach in which an additional language is used for the learning and teaching of both content and language" (Coyle et al., 2010, p.1). That is, in the teaching and learning process, there is a focus divided between content and language, as well as varying degrees of emphasis on one or the other at a given time. CLIL is "a general umbrella term" (Kovács, 2014, p.48-49), and attention is given to both topic and language of instruction. When teaching through a foreign language, both non-language content and language requires a special approach to teaching; more specifically, the content of the non-language subject is taught with the language serving simultaneously as a medium of instructing the non-language subject but also as a different subject matter learnt.

Using daily a language other than one's mother tongue dates back to antiquity, as diverse ethnic groups coexisting in multilingual territories used bilingualism or even plurilingualism to survive (Pokrivčáková et al., 2015). Upper class males and females were offered foreign language learning either through instruction and tutoring or through language immersion in the target country (Pokrivčáková et al., 2015). Content-based language learning in real context was primarily expressed in Central Europe by the pedagogues J. A. Comenius and M. Bel (Pokrivčáková et al., 2015). Minimizing teaching of grammar rules, Bel endowed the teaching process with the cultural context of languages and also inspired teachers of Latin to engage in meaningful uses of language in everyday and vocational functions (Pokrivčáková et al., 2015).

Historically, schools in which the teaching of certain subjects in the curriculum may be offered in a foreign, regional or minority language have existed in Europe for several decades. Before 1970, CLIL instruction was a decision on the basis of geographic, demographic or financial criteria, restricted to areas near national borders or to big urban agglomerations and consequently, focusing on a minority of student population, that is, on students living in contexts which favored bilingualism (Pokrivčáková et al., 2015). The objective was to turn the taught students into bilingual children by making them able to acquire high proficiency in the second language (Eurydice, 2006).

The Canadian experiment of French immersion teaching has been focal in the early provision of CLIL. It stemmed from Canadian English-speaking parents' will to offer their kindergarten children an equal opportunity "a) to become competent to speak, read and write in French; b) to reach normal achievement levels throughout the curriculum, including the English language; c) to appreciate the traditions and culture of French-speaking Canadians, as well as Englishspeaking Canadians" (Baker, 1993, p.496).

Respectively, overseas there was the LAC (Language across the Curriculum) movement. It began in England with a group of English secondary teachers who aimed at analyzing the role of discussion in English lessons. They reckoned it "impossible to confine their study to English lessons alone" and found themselves "discussing the relationship between language and thought, how language represented experience, the functions of language in society, different kinds of language and how they were acquired" (Parker, 1978, p.173). This discussion gave birth to the 
idea of language across the curriculum, stimulating further research and spreading through England, Australia and Canada. In the USA the idea was used with major emphasis on the development of students' writing skills (Pokrivčáková et al., 2015).

The aforementioned success of the Canadian experiment attracted European interest regarding language policy (Pokrivčáková et al., 2015). In 1978, a proposal was issued by the European Commission (EC) which fostered teaching in schools through more than one language (Marsh, 2002). In 1983, the EC was requested to promote a new program with the objective of ameliorating foreign language teaching (Marsh, 2002). Gradually and before the creation of European schools, more state schools, especially in capital cities of the EU, had included immersion programs in their curriculum (Pokrivčáková et al., 2015). According to Marsh (2012), there were political and educational dimensions in the European launch of CLIL during 1994. With regard to the political dimension, the vision of greater mobility across the EU countries called for higher levels of language competence than the existent ones at that time regarding EU languages (Marsh, 2012). Concerning the educational dimension, the objective was to design novel teaching approaches or modify existent ones so as to offer higher levels of language competence to a broad range of students (Marsh, 2012).

In 2006, CLIL was available in most European member states and mostly in secondary education. Few EU countries - Austria, Finland, Hungary and Spain - had implemented early education programs (Kovács, 2014, p.51). During the last decade, there has been abundant research on CLIL, but mostly on its linguistic elements (Marsh, 2012, p. V). Thanks to recent research, a third element has supplemented the duality of language and content in CLIL, and this element is the focus on students' learning strategies and thinking skills (Mehisto et al., 2008).

\section{Interculturalism in Content and Language Integrated Learning Classes}

CLIL is "mainly about helping learners develop strategies in order to acquire knowledge in a subject through a foreign language" (Mattheoudakis et al., 2018, p.104). It can be regarded as a flexible tool with a diversity of benefits and its flexibility is highlighted by the 4C model, which integrates content, communication, cognition and culture (Harrop, 2012). The benefits from CLIL instruction can be investigated not only in language and content gain but in raising intercultural awareness as well.

Enhancing intercultural communication and preparing for internationalization constitutes an educational challenge in the globalized reality of the $21^{\text {st }}$ century. If education is a "language socialization of learning" (Mohan, 1987), then CLIL corresponds ideally through the combination of context, language and cognition, which forms the perfect conditions for reflection, self-awareness, while re-appropriating students' language as a learning tool in their own context (Broady, 2004). The dual emphasis of CLIL on language learning and content learning apparently offers the perfect conditions for intercultural learning.

Since content is "never culturally neutral" (Sudhoff, 2010, p.30), the analysis, reformation, comparison and contrast of one's cultural standpoint with foreign cultural points of view is paramount in exploring diverse cultural viewpoints and developing intercultural competence. 
CLIL is beneficial thanks to "providing learners with experiences that would have been impossible in a monolingual or traditional MFL (Modern Foreign Language) setting" (Harrop, 2012, p.66). Besides approaching a culturally loaded topic from one's own cultural standpoint, a foreign viewpoint can be reached and (re)structured by means of the target language.

Kramsch's (1993) reference to the possibility for foreign language learners to enrich their cultural identity based on interculturality can be realized in CLIL. Skopinskaja (2003, p.40) states: "In acquiring knowledge about and reflecting on the target language culture, students need to be encouraged not simply to observe similarities and differences between the two cultures, but they should also analyze them from the viewpoint of the others and try to establish a relationship between their own and other systems". Target language immersion through CLIL in order to understand content enhances fluency before accuracy and meaning before form (Littlewood, 2004). Students are immersed and involved in authentic language to carry out content tasks, and what ensues at a micro-level is autonomous learning (Dam, 1995; Papadopoulos \& Griva, 2014; Papadopoulos et al., 2016), active structuring of knowledge (Wolff, 2002) and cooperation.

Lastly, being a global language, English offers greater opportunities for enhancing intercultural awareness in comparison to CLIL in other languages, because it multiplies exponentially the variety of potential chances for contacting a wider range of cultures.

\section{Linguistic and Cultural Diversity with CLIL as a Part of the European Language Policy}

The conceptualization of Content and Language Integrated Learning as a European construct proves the institutional, country-specific or EU - specific addressing of the complicated issues of the diversity of languages and cultures in the EU, of cross-border professional mobility and of EU professional and economic competitiveness. In short, CLIL's broad terms of reference incorporate "many of the language issues supported by" the European Commission, "the Council of Europe, the European Charter for Lesser Used Languages, the Declaration of Oegstgeest, the Universal Charter for Language Rights"(Marsh, 2002, p.24).

CLIL aligns itself with the European Language Policy for improving language learning in its member states and with the EU Commission's objective of EU citizens' competence in European languages other than learners' mother tongue. With its potential to cover all likely combinations of promoting language thanks to boosting early language learning, teaching subject through language, trilingualism (European citizens' competence in two European languages on top of their mother tongue or national languages) "CLIL harmonizes itself with EU practices" (Marsh, 2002, p.35) and concurrently prepares students for internationalization through international certification (Darn, 2006). In this light, the need of a CLIL approach in those European bilingual communities in which schools must account for the teaching/learning of two national languages must be particularly emphasized. CLIL's all-inclusive potential flexibly encompasses students living close to borders between European countries, minority language students, immigrant students, as well as native speakers of the main language aiming at increasing their target language competences. 
Furthermore, CLIL aligns itself with two different types of language learning goals, that is, learning a foreign language and learning a heritage language of minorities or migrant populations, promoting linguistic and, thus, cultural acceptance in both cases. These two goals differ also in terms of methodology, but such a difference is recognized by European policymakers by the establishment of the European Bureau for Lesser-used languages (EBLUL) as a non-governmental organization and an institution of European interest financed by the EU (Marsh, 2002).

In a curriculum packed with courses, and regarding language teaching to new target groups, CLIL offers the answer, as "as one of the ways to achieve the objective of learning two languages in addition to the mother tongue" (European Commission, 2003 p.2). In the European Commission's Action Plan for Language Learning and Linguistic Diversity, CLIL is regarded as an innovative method to improve language teaching. The European Label for innovative projects in language teaching and learning, as well as the Leonardo and Socrates programs (European Commission, 2003, p.2) constitute initiatives for CLIL promotion. CLIL networks providing platforms for CLIL teachers, decision-makers and others interested in CLIL are CLILCOMPENDIUM, CLILCOM (CLIL Competencies, a multimedia tool for raising awareness of and supporting the development of teacher competencies in CLIL) and EUROCLIL (European Network of Administrators, Researchers and Practitioners).

\section{CLIL Organizations}

The European Union, the European Commission and the Council of Europe offer support for CLIL. So far CLIL has been applied in countries of the EU, but mostly in the stage of its implementation and to a much smaller extent in terms of teacher preparation and training programs. Internationally, several CLIL organizations have been operating:

\section{UNICOM}

This particular organization has been engaged in CLIL projects beyond Europe, in African countries such as Namibia and Ethiopia, where CLIL is employed as a means for minimizing discrimination and teacher and student exclusion on the basis of inadequate knowledge of the language of instruction. UNICOM is also the coordinator of the CLIL Consortium, "a growing collection of experts in the field of bilingual and content-based education" (Darn, 2006, p.5). It has produced considerable research regarding CLIL, engaging numerous researchers.

\section{EuroCLIL}

Concerning the activities of this organization, it aims at boosting information, experience and materials exchange among CLIL players and at helping them pursue their interests nationally and at a European level. Its secretariat is in charge of coordinating all actions of the network; electronic communication via an email newsletter offers the chance of locating potential project partners, promoting CLIL courses, providing research information, among others; the EuroCLIL website offers useful information regarding the network, registration as well as links to other 
relevant European and national organizations.

\section{The TIE-CLIL project}

The TIE-CLIL project has been a funded programme through Socrates which promotes multilingualism by means of employing CLIL in five languages of the EU (English, French, German, Italian and Spanish). TIE-CLIL aims at offering "pre- and in-service development programs in CLIL for language teachers and subject teachers"(Darn, 2006, p.5)and at developing CLIL theoretical instruction and practical implementation through five modules, namely, Main Features of CLIL (Module 1), Second Language Acquisition for CLIL (Module 2), Practical Aspects for Teaching in CLIL (Module 3), Language Awareness in Bilingual Teaching (Module 4) and CLIL for the Learner (Module 5).

\section{CLILCOM}

It is worth mentioning that CLILCOM is an e-platform endowing its users with professional competence in order to enable them to teach through a foreign language. It functions as a tool offering personalized consulting services. Made for both language and content teachers, it constitutes a significant CLIL-enhancing resource for educators in the fields of professional and vocational instruction.

\section{The CLIL Compendium}

As far as CLIL Compendium is concerned, it "identifies" most comprehensively "the foundations, benefits, dimensions, progress and potential of CLIL across Europe and is the result of a multinational research project" (Darn, 2006, p.6).

However, it is evident that, apart from the organizations functioning at an international level, it is worth examining country-specific CLIL initiatives in Europe.

\section{CLIL's Position within the Greek Education Context}

According to the most recent official data from Eurydice $(2012,2017)$, all countries in Europe apart from Greece, Denmark and Iceland offer some type of CLIL instruction but this is not widespread. In Greece so far CLIL has been implemented in primary school education (Paschalidou, 2018; Papadopoulos \& Griva, 2014) as a sequel of localized, bottom-up initiatives, and not as a result of official policies.

So far CLIL projects have been implemented "to young students (aged 8-12 years) with the purpose of interweaving language and content learning: that is, to develop students' foreign language skills simultaneously with enhancing their knowledge in aspects of history and developing their cultural awareness and multicultural understanding" (Griva \& Kasvikis, 2014, p. 125 ). In the Greek context, CLIL projects were implemented because the CLIL innovation does not demand more hours to be devoted to language teaching "in an already crowded curriculum" (European Commission, 2004, p. 2). Also, they were implemented as CLIL,being incorporated into the curriculum of other subjects (Dalton-Puffer, 2011), can render language 
competence naturally acquired in the minimum amount of time, as students focus on the communicated meaning rather than the form. Lastly, CLIL projects were implemented because CLIL is believed to increase motivation and enhance positive attitudes towards language learning (Charalamboglou \& Papadopoulos, 2019; Van de Craen, Ceuleers \& Mondt, 2007).

To sum up, although CLIL has a limited history in Greece, some conclusive evidence for its implementation has led to framing suggestions for its appropriate implementation in the Greek context.

\section{Concluding Remarks}

CLIL has been proven to contribute to students' both linguistic and cognitive development. Multicultural Issues, the most common objective in CLIL projects (Sakellariou et al, 2019), aims by unveiling diverse countries and cultures, to bridge their diversity. Young learners have fewer negative attitudes to foreign languages and cultures (Brumfit, 1991). This is achieved by enhancing positivity towards plurilingualism and pluriculturalism thanks to the fact that via different perspectives in approaching a topic, one gains more in-depth awareness of mother tongue, target language and diverse cultures. In CLIL, the establishment of a meaningful learning context and the employment of the foreign language as an instrument for discovering and constructing meaning causes decentralization in students' linguistic view of the world and subsequently room for intercultural learning (Coffey, 2005).

Based on a study conducted by Sakellariou, Papadopoulos and Karoulla-Vrikki (2019), it was also shown that Geography-oriented content is also used to a great extent in the Greek EFL education. In particular, such courses which bring to classroom the real world, and young students learn things about the real world through language (Snow, Met \& Genesee, 1989) are selected in order to serve as the content in CLIL classrooms. As a consequence, learning subject matter through the target language is related to target language fluency, as well as to oral communication skills. Thus, CLIL can boost interest in languages other than the mother tongue, as the process of language learning seems more approachable thanks to learning interesting Geography and Environmental content, which is encyclopedic and gives answers to young learners' cognitive quest for knowledge.

Thanks to CLIL, students become more profoundly aware of their mother tongue and the target language, and enhance their positive attitudes towards plurilingualism (Klimova, 2012). The aforementioned in-depth awareness of both the mother tongue and the target language emanates from the fact that through CLIL the linguistic issues in subject-content are manifested in a manner frequently non-existent in non-language subjects (Bearsmore, 2008; Mehisto, 2008). This increases CLIL teachers' consciousness as to the students' linguistic needs and also their effectiveness with regard to enhancing understanding (Muñoz, 2002).

CLIL is also linked positively to academic language and language complexity (Maillat, 2010), as well as to morphosyntactic features' acquisition (Hüter \& Rieder-Bünemann, 2010). Concerning the latter, CLIL tasks motivate learners to become more conscious of target language form, as well as more systematic in their self-correction of target language form (Lyster, 2007). 
This is achieved through teacher prompts to elicit CLIL, through transferring students' focus from semantic to syntactic processing, through enabling them to "reconstruct their interlanguage efficiently" and "sustain their linguistic growth" (Harrop, 2012, p.61).

Regarding skills, most CLIL students demonstrate higher proficiency and improved communicative skills compared to non-CLIL students (Harrop, 2012). Comparatively, the former are characterized by a far better performance than the latter in receptive skills (listening and reading), in fluency, but less frequently so with regard to productive skills and, more specifically, in terms of pronunciation, complexity and accuracy of written and spoken language (DaltonPuffer, 2007 \& 2008; Lasagabaster, 2008; Alonso et al., 2008; Naves, 2009; Ruiz de Zarobe, 2008).

Moreover, improved content knowledge is due to the interconnection between content and language and the cognitive challenges it poses through CLIL. In other words, CLIL also reinforces content teaching by nurturing cognitive development and flexibility among students, as well as by accepting the importance of language as focal in learning (Lyster, 2007; DaltonPuffer, 2008).

Consequently, CLIL learners can be involved in individual and cooperative learning more profoundly, and, concurrently, go through the process from the viewpoint of their counterparts (Coffey, 2005). CLIL learning through the content of Multicultural Issues, Geography and Environmental Studies extends at a micro-level, through purposeful, content-oriented communication in the target language and possibly, at a macro level, by endowing pupils with the linguistic potential to extend their communication outside the classroom with the objective of cognitive development (Coyle et al., 2010).

Taking everything into consideration, it is advisable that teachers in Greece participate in professional development programs with regard to CLIL. In this way, they may be equipped with appropriate knowledge, skills and competencies that will facilitate their awareness of this approach, their experimentation with lesson planning and implementation. Meanwhile, they will be offered ample opportunities for sharing ideas, experiences and practices which can constitute both stimuli for further research and for further development of their teaching practices for the sake of their students' linguistic and content development.

\section{References}

Alonso, E., Grisalena, J. \& Campo, A. (2008). Plurilingual Education in Secondary Schools: Analysis of Results. International CLIL Research Journal, (1) 1, 36-49

Baker, C. (1993). Foundations of bilingual education and bilingualism. Mulilingual Matters

Beardsmore, H. (2008). Language promotion by European supra-national institutions. In O. García (Ed.), Bilingual education of the 21st century: A global perspective (pp. 197-217). Oxford: Wiley-Blackwel

Broady, E. (2004). Sameness and Difference; the Challenge of Culture in Language Teaching. Language Learning Journal , 29, 68-72

Brumfit, C.J (Ed.) (1991). Assessment in Literature Teaching Review of English Language Teaching, 1 (3). London: Modern English Publications in association with the British Council.

Charalampoglou, N. \& Papadopoulos, I. (2019). CLILing with Young Language Learners: a multidimensional 
reflection on teaching practices in Greek foreign language education. Published in the Proceedings of the 5th International Conference on the Promotion of Education Innovation. Larissa, 11 - 13 October 2019

Coffey, S. (2005). Content-based Learning, in Cerezal, F. De la Práctica a la Teoría: Reflexiones sobre la Enseñanza y el Aprendizaje de Inglés. Alcalá de Henares: Universidad de Alcalá, 49-62

Coyle, D., Hood, P. \& Marsh, D. (2010). CLIL - Content and Language Integrated Learning. Cambridge: Cambridge University Press.

Dalton-Puffer, C. (2008). Outcomes and Processes in Content and Language Integrated Learning (CLIL): Current Research from Europe, in Delanoy, W. \& Vokmann, L. Future Perspectives for English Language Teaching. Heidelberg: Carl Winter, 139-157

Dalton-Puffer, C. (2007). Discourse in CLIL Classrooms. Amsterdam: John Benjamins.

Dalton-Puffer, C. (2011). Content-and-Language Integrated Learning: from Practice to Principles. Annual Review of Applied Linguistics, 3, 182-204

Dam, L. (1995). Learner Autonomy. 3: From Theory to Classroom Practice. Dublin: Authentic.

Darn, S. (2006). Content and Language Integrated Learning (CLIL) A European Overview. Izmir: Izmir University of Economics.

European Commission.(2004). Many tongues, one Family: Languages in the European Union. Brussels: European Commission.

Eurydice. (2017). Key Data on Teaching Languages at School in Europe. Brussels: Eurydice Education.

Eurydice. (2006). Content and Language Integrated Learning at School in Europe. Brussels: Eurydice Education.

Griva, E. \& Kasvikis, K. (2014). CLIL in Primary Education: Possibilities and Challenges for Developing L2/FL Skills, History Understanding and Cultural Awareness. in Baki?-Miri? N. \& Erkinovich Gaipov D., Current Trends and Issues in Education: an International Dialogue. Cambridge Scholars Publishing

Harrop, E.(2012) Content and Language Integrated Learning (CLIL): Limitations and Possibilities. Encuentro, 21, $57-70$

Hüter, M.J. \& Rieder-Bünemann, A. (2010). A Cross-sectional Analysis of Oral Narratives by Children with CLIL and non-CLIL Instruction. in Nikula, C.T. and Smit, U.: Language Use and Language Learning in CLIL Classrooms. Amsterdam: John Benjamins, 61-80

Klimova, B. F. (2012). CLIL and the Teaching of Foreign Languages. Procedia - Social and Behavioral Sciences , $47,572-576$

Kovács, J. (2014). CLIL - Early Competence in two Languages. In Kovács, J. \& Benkő, É. T. (Eds.), The World at Their Feet: Children's Early Competence in Two Languages through Education (p. 15-97). Budapest: Eötvös József Könyvkiadó.

Kramsch, C. (1993). Context and Culture in Language Teaching. Oxford: Oxford University Press.

Lasagabaster, D. (2008). Foreign Language Competence in CLIL Courses. The Open Applied Linguistics Journal, 1, $31-42$

Littlewood, W. (2004). The Task-based Approach: some Questions and Suggestions, ELT Journal 58 (4), $319-326$

Lyster, R. (2007). Content and Language Integrated Teaching: a Counterbalanced Approach. Amsterdam: John Benjamins.

Lyster, R. (2007). Learning and Teaching Languages through Content: A Counterbalanced Approach. Amsterdam: John Benjamins.

Maillat, D. (2010). The Pragmatics of L2 in CLIL. in Dalton-Puffer, C., Nikula, T. \& Smit, U.: Language Use and Language Learning in CLIL Classrooms. Amsterdam: John Benjamins, 39-60

Marsh, D. (2012) Content and Language Integrated Learning (CLIL). A Development Trajectory. Córdoba: University of Córdoba. 
Marsh, D. (2002). CLIL/EMILE - the European Dimension: Actions, Trends and Foresight Potential. University of Jyväskylä.

Mattheoudakis, M., Alexiou, T. \& Ziaka, I. (2018). The Impact of CLIL Instruction on Content Learning: Evidence from the Greek Context. International Journal of Innovation in Education, 5 (2), 92-109

Mehisto, P. (2008). CLIL Counterweights: Recognising and Decreasing Disjuncture in CLIL. International CLIL Research Journal, 1 (1),93-120

Mehisto, P., Marsh, D. \& Frigols, M.J. (2008). Uncovering CLIL: Content and Language Integrated Learning in Bilingual and Multilingual Education. Oxford: Macmillan.

Mohan, B. (1986/7). Language and Content. Reading, MA: Addison - Wesley

Navés, T. (2009). Effective Content and Language Integrated Learning (CLIL) Programmes. In Ruiz De Zarobe, Y. \& J. Catalan, R. M. (Eds.) CLIL: evidence from research in Europe. Bristol: Multilingual Matters.

Papadopoulos Is \& Griva, E. (2014). "Learning in the traces of Greek culture": A CLIL Project for raising cultural awareness and developing L2 skills, International Journal of Learning, Teaching and Educational Research, Vol. 8, No.1, pp. 76-92

Papadopoulos, Is., Theologou, E. \& Theologou, M. (2016). Building Bridges with the Parables: Developing Bilingual Students' EFL Skills within a Multimodal Learning Environment. International Journal on Studies in English Language and Literature, 4 (2), pp. 1-6

Parker, R. (1978). The Language Across the Curriculum Movement: A Brief Overview and Bibliography. College Composition and Communication, 36 (2), p. 173 - 177

Paschalidou G. (2018). Content and Language Integrated Learning (CLIL) in Europe and Greece: Common Practices and Effectiveness, Limitations and Suggestions in Tsokalidou R. \& Kekia M.A., 4th Crossroads of Languages and Cultures: "Multilingual Educational Approaches and Language Policies" International Conference Proceedings,355-371

Pokrivčáková, S., Babocká, M.,Bereczky, K., Bodorik, M., Bozdogan, D., Dombeva, L., Froldova, V., Hanesová, D., Hurajová L., Leung, P., Luprichová, J., Sepesiová, M., Simonová, I., Straková, Z., Trniková, J., Xerri, D., Zavalari, K. (2015). CLIL in Foreign Language Education: e-textbook for foreign language teachers. Nitra: Constantine the Philosopher University.

Ruiz de Zarobe, Y. (2008). CLIL and Foreign Language Learning: a Longitudinal study in the Basque Country. International CLIL Research Journal, 1 (1), 60-73

Sakellariou, G., Papadopoulos, I. \& Karoulla-Vrikki, D. CLIL implementation within the Greek EFL education context: from the European language policy to teaching practice. Published in the proceedings of the 5th International Conference on the Promotion of Education Innovation. Larissa, 11 - 13 October 2019

Skopinskaja, L. (2003). The Role of Culture in Foreign Language Teaching Materials: an Evaluation from an Intercultural Perspective. In: Lázár, I.: Incorporating Intercultural Communicative Competence in Language Teacher Education. Strasbourg: Council of Europe Publishing, 39-58

Snow, M. A., Met M.\& Genesee, F. (1989). A Conceptual Framework for the Integration of Language and Content in Second/Foreign Language Instruction. TESOL Quarterly, 23 (2), 201-217

Sudhoff, J. (2010). CLIL and Intercultural Communicative Competence: Foundations and Approaches towards a Fusion. International CLIL Research Journal, 1 (3), 30-37

Van De Craen, P., Ceuleers, E. \& Mondt, K. (2007). Cognitive Development and Bilingualism in Primary Schools: Teaching Maths in a CLIL Environment. In D. Marsh \& D. Wolff (eds.) Diverse Contexts-Converging Goals: CLIL in Europe. Frankfurt am Main: Peter Lang, 185-200

Wolff, D. (2002). Eine Fremdsprache als Arbeitssprache Gebrauchen: Bilingualer Sachfachunterricht und Deutschsprachiger Fachunterricht. Buenos Aires Ausgewählte Texte zu einzelnen Aspekten des Seminars. 